\title{
Kajian Proses Pengeringan Pinang Muda (Areca catechu L) Menggunakan Bahan Bakar Biomassa Kayu : Studi Kasus PT. Areca Agro Aceh
}

\section{(Study of Batel Nut (Areca catechu L) Drying Process Using Wood Biomass Fuel: A Case Study of PT. Areca Agro Aceh)}

\author{
Cut Nazila Fitri ${ }^{1}$, Raida Agustina ${ }^{1}$, Indera Sakti Nasution ${ }^{1}$ \\ Program Studi Teknik Pertanian, Fakultas Pertanian, Universitas Syiah Kuala \\ *Corresponding author: i.nasution@unsyiah.ac.id
}

\begin{abstract}
Abstrak. Pengeringan pinang muda menggunakan bahan bakar biomassa kayu dapat dilakukan dengan cara pengovenan. Pengeringan dilakukan sebanyak 3 kali pengulangan pada suhu $60^{\circ} \mathrm{C}$, perhitungan masa pinang diukur tiap 3 jam untuk 24 jam pertama, tiap 6 jam untuk hari ke-2 sampai sampai massa bahan konstan. Parameter penelitian untuk mengetahui pinang kering berdasarkan perubahan bobot bahan dan kadar air meliputi laju pengeringan, kecepatan aliran udara, kelembaban udara, suhu dan perubahan berat bahan.

Hasil penelitian pada PT. Areca Agro Aceh dalam proses pengeringan pinang muda kering dengan menggunakan bahan bakar biomassa kayu menghasilkan rata-rata kelembaban udara sebesar $56 \%$ dengan kecepatan aliran udara rata-rata sebesar $2,22 \mathrm{~m} / \mathrm{s}$. Untuk mendapatkan berat pinang muda kering yang konstan, pengeringan ulangan 1 dan ulangan 2 membutuhkan waktu sampai 90 jam sedangkan ulangan 3 membutuhkan waktu pengeringan sampai 96 jam dengan ulangan 1 kadar air awal pinang muda adalah $74,4 \%$. Perubahan mulai terjadi pada jam ke 24 sampai jam ke 90 dengan kadar air akhir pinang muda adalah 22,4\% sedangkan pada ulangan 2 kadar air awal pinang muda adalah 74,0\% selama 90 jam pengeringan menghasilkan kadar akhir sebesar 21,1\%. Pengeringan pinang muda pada ulangan 3 kadar air awalnya sebesar 74,2\% menghasilkan kadar air akhir sebesar 21,8\% selama 96 jam pengeringan. Laju pengeringan rata-rata selama proses pengeringan sebesar $0,04 \mathrm{bk} / \mathrm{jam}$. Peningkatan laju pengeringan terjadi pada jam ke 21.
\end{abstract}

Kata Kunci : Pinang Muda, Biomassa Kayu dan Oven.

Abstract. Drying young areca nut using wood biomass fuel can be done by covenant. Drying is done 3 times repetition at a temperature of $60 \mathrm{oC}$, calculation of areca nut mass is measured every 3 hours for the first 24 hours, every 6 hours for the 2nd day until the mass of material is constant. Research parameters to determine the dry areca nut based on changes in material weight and moisture content include drying rate, air flow velocity, air humidity, temperature and material weight change.

The results of research at PT. Areca Agro Aceh in the process of drying areca nut dry using wood biomass fuel produces an average air humidity of $56 \%$ with an average air flow velocity of $2.22 \mathrm{~m} / \mathrm{s}$. To get a constant weight of dry young areca nut, drying repetition 1 and repetition 2 takes up to 90 hours while repetition 3 requires drying time up to 96 hours with repetition 1 The initial water content of young areca nut is $74.4 \%$. Changes began to occur at the 24th hour to the 90th hour with the final water content of young areca nut being $22.4 \%$ while in Repeat 2 the initial water content of the areca nut was $74.0 \%$ for 90 hours of drying resulting in a final content of $21.1 \%$. Drying young areca nut on replicate 3 , the initial water content of $74.2 \%$ produced a final water content of $21.8 \%$ for 96 hours of drying. The average drying rate during the drying process is $0.04 \mathrm{bk} /$ hour. Increased drying rate occurs at 21 hours.

Keywords : Young Areca Nut, Wood Biomass and Oven

\section{PENDAHULUAN}

Pinang muda (Areca catechu L) merupakan salah satu buah yang dapat digunakan untuk menjaga kesehatan. Di Aceh buah pinang biasanya digunakan untuk pelengkap tradisi memakan sirih. 
Selain itu pemanfaatan pinang muda lainnya adalah untuk pembuatan permen pinang, seperti yang dilakukan oleh PT. Areca Agro Aceh.

PT. Areca Agro Aceh berdiri pada tahun 2014 yang dipimpin oleh bapak H. Abdullah Amin, kemudian pada tahun 2015 usaha dagang tersebut diresmikan menjadi PT. Areca Agro Aceh. Perusahaan ini memproduksi pinang muda yang dikeringkan untuk dijadikan permen, yang kemudian akan diekspor ke luar negeri untuk diolah ulang menjadi permen pinang dengan tidak merubah bentuk asli dari buah pinang tersebut, perusahaan ini menerima pinang muda segar dengan kriteria 8 minggu dari masa pemekaran bunga.

\section{METODOLOGI PENELITIAN}

\section{Waktu dan Tempat}

Penelitian ini dilakukan pada Bulan Februari - Juli 2018 di PT. Areca Agro Aceh Jl. Medan Banda Aceh Sungai Raya. Kecamatan Sungai Raya Kabupaten Aceh Timur.

\section{Alat dan Bahan}

Alat yang digunakan adalah meja sortir, bak perebusan, oven, timbangan analitik, termometer termometer infrared dan humiditymeter, anemometer dan bahan yang digunakan ialah pinang muda, air dan kayu untuk bahan bakar proses pengeringan dilakukan secara continue dengan kayu dibelah menjadi beberapa bagian kemudian dimasukkan kedalam dapur pembakaran.

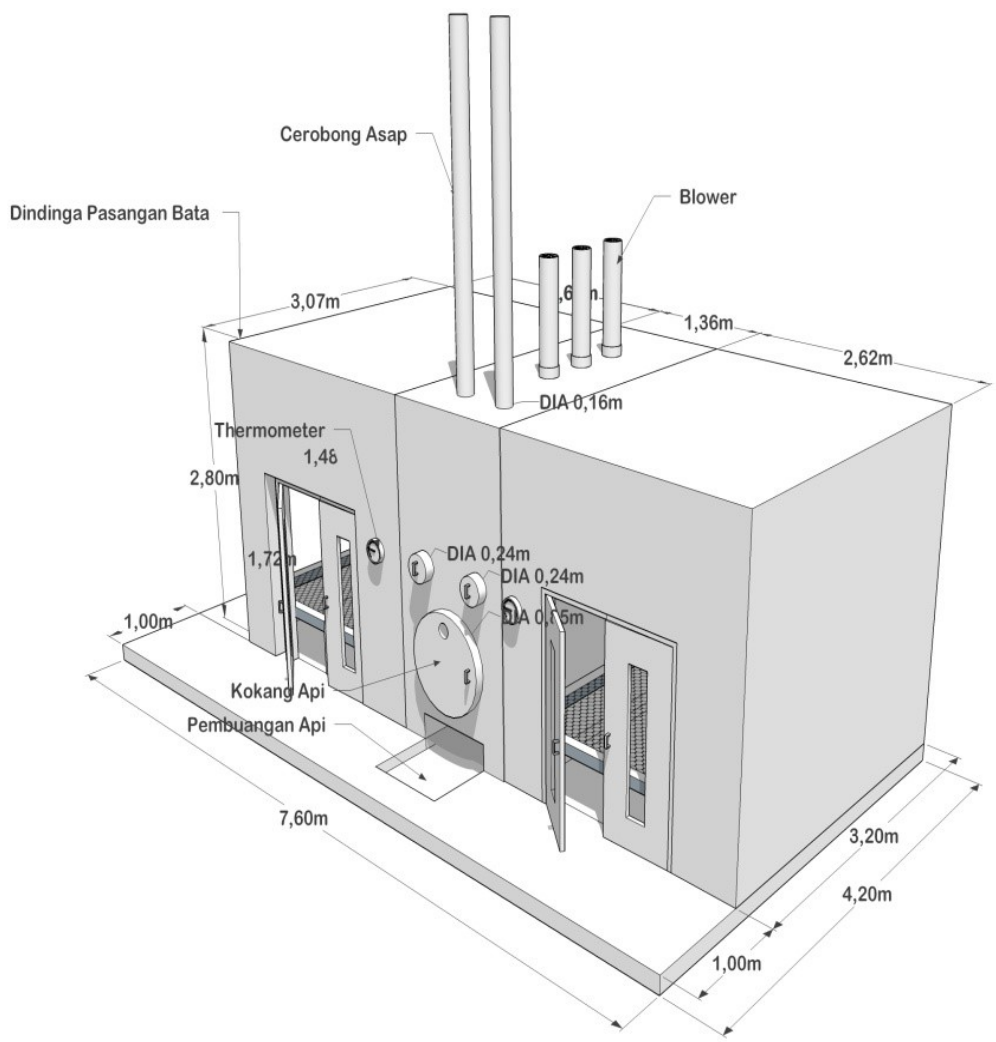

Gambar 1. Oven pengeringan pinang 


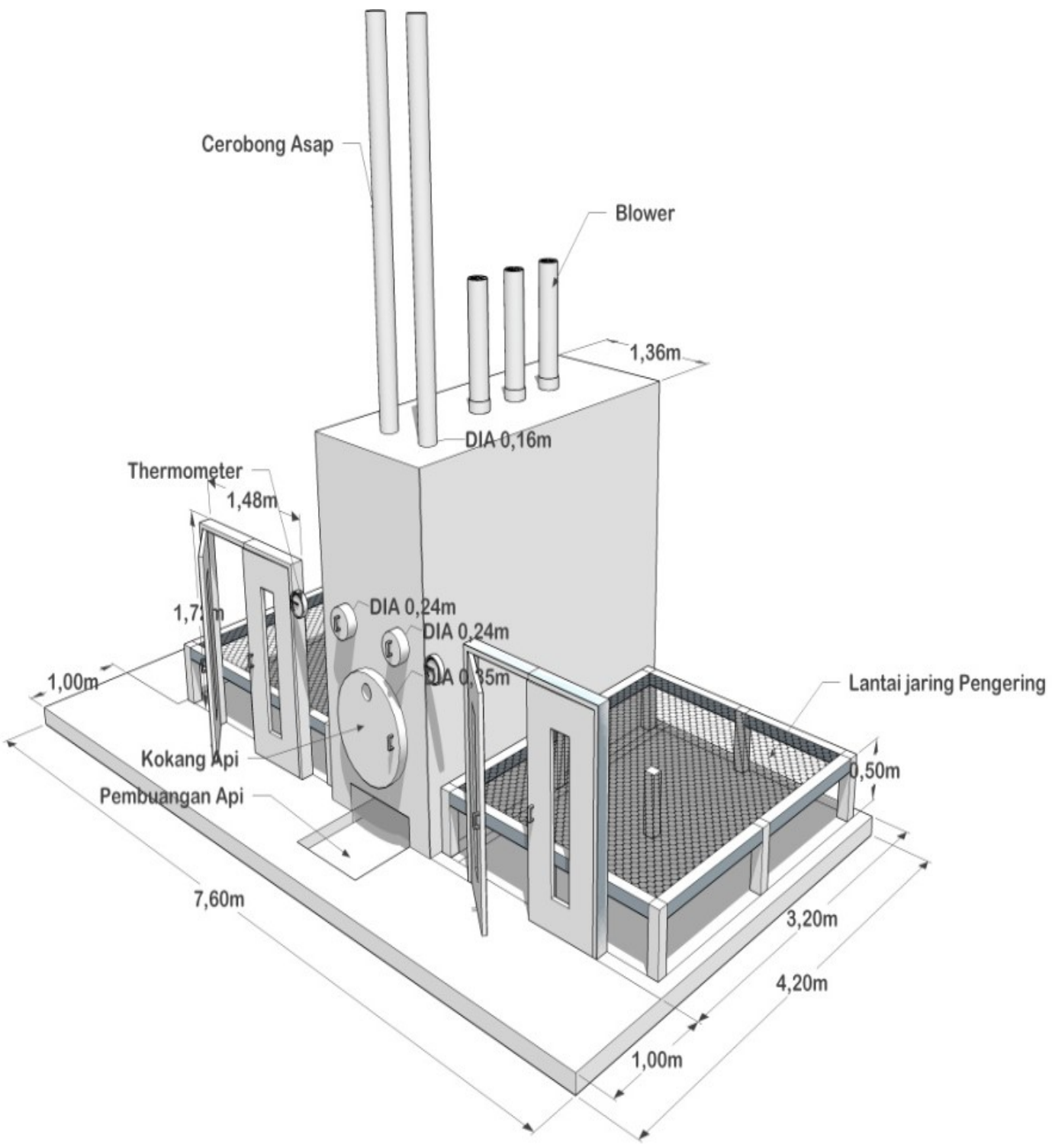

Gambar 2. Bagian dalam oven pengeringan pinang

Untuk suhu ruang pengeringan oven sebesar $60^{\circ} \mathrm{C}$ telah ditetapkan oleh pihak PT. Areca Agro Aceh. Sumber suhu dihasilkan dari biomassa kayu diberikan saat proses pengeringan yang sedang berlangsung selama 99 jam (4 hari), sehingga pengeringan pinang muda tidak terjadi penjamuran saat proses pengeringan

\section{Metode Pengambilan Data}

Adapun metode yang dilakukan di PT. Areca Agro Aceh sebagai berikut : 
diperlihatkan pada Gambar 4 seperti berikut :

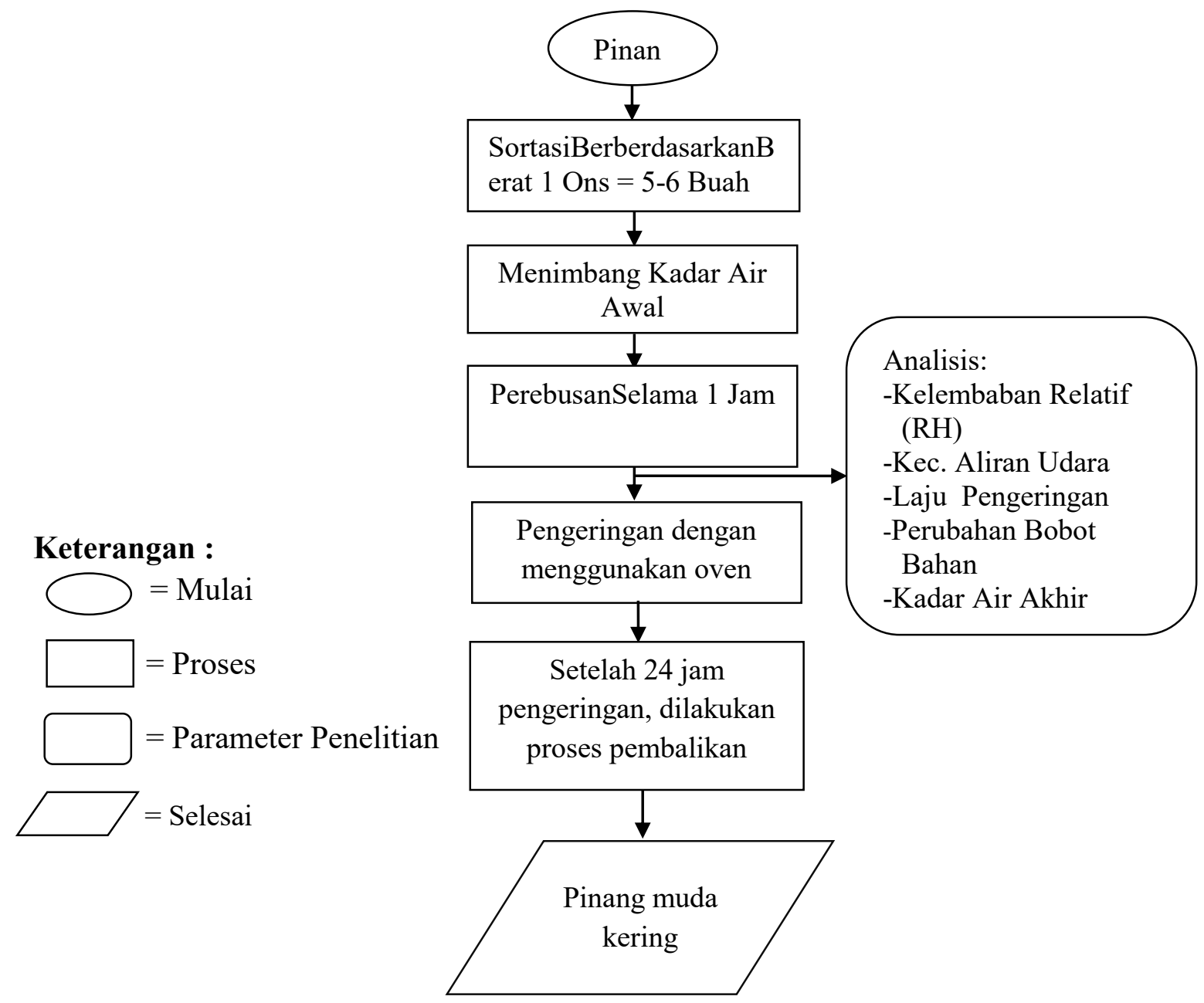

Gambar 4. Diagram alir penelitian

\section{Prosedur penelitian}

Adapun prosedur Penelitian adalah sebagai berikut : (1) Buah pinang disortasi untuk memisahkan ranting, buah tua dan menyeragamkan ukuran buah pinang muda berdasarkan berat dimana dalam 1 ons terdapat 5-6 buah. Selajutnya untuk mendapatkan berat awal pinang di timbang,

(2) Buah pinang direbus selama 1 jam dengan suhu $100 \mathrm{oC}$ kemudian diukur kadar air setelah perebusan, (3) Setelah dilakukan perebusan buah pinang dimasukkan kedalam oven untuk proses pengeringan, oven pengering pinang dapat dilihat pada Gambar 2, Gambar 3, dan Gambar 4. (4) Selama proses pengeringan dicatat data distribusi $\mathrm{RH}$, kec. aliran udara dan laju pengeringan selama per $3 \mathrm{jam} / \mathrm{hari} 1$ berikutnya per 6 jam/hari ke 2 sampai kadar air konstan.

Untuk mengukur kadar air awal ialah bahan ditimbang sebanyak 5 gram di dalam aluminium foil yang telah diketahui berat kosongnya. Kemudian bahan tersebut dikeringkan dalam oven dengan suhu sekitar $105^{\circ} \mathrm{C}$ selama 3 jam, selanjutnya didinginkan di dalam desikator selama 15 menit lalu ditimbang kembali. Setelah itu, bahan dipanaskan kembali di dalam oven selama 30 menit, kemudian didinginkan kembali dengan desikator selama 15 menit lalu ditimbang. Perlakuan ini diulangi sampai diperoleh berat yang konstan (AOAC, 1984).

\section{Analisa Pengeringan Pinang Muda Kering}


Adapun analisa mutu yang di jabarkan meliputi :

\section{Perubahan bobot bahan}

Bobot bahan dilakukan dengan cara menimbang berat bahan pada hari ke-n dan membandingkannya dengan berat biji pada hari yang digunakan adalah

Susut bobot $=\frac{a-b}{a} \times 100 \%$

Keterangan : $\mathrm{a}=$ berat awal

$$
\mathrm{b}=\text { berat biji pada ke-n. }
$$

\section{Prosedur Pengujian Kadar Air Dengan Menggunakan Metode Oven}

Kadar air merupakan salah satu sifat fisik dari bahan yang menunjukkan banyaknya air yang terkandung di dalam bahan

$M(b b)=\frac{\mathrm{w} 1-\mathrm{w} 2}{\mathrm{w} 1} \mathrm{X} 100 \%$

Keterangan :

$\mathrm{M}(\mathrm{bb})$ : Kadar air basis basah (\%)

w1 : Berat awal bahan (g)

w2 : Berat kering bahan konstan (g)

\section{Teknik Analisa Data} meliputi :

Data penelitian dijabarkan secara deskriptif, dan ditampilkan dalam bentuk grafik, yang

1. Grafik distribusi kelembaban udara (RH) terhadap waktu (t).

Pengukuran kelembaban relatif dilakukan dengan menggunakan humudity meter.

2. Grafik kecepatan udara terhadap waktu (t).

Pengukuran kecepatan udara dilakukan dengan menggunakan alat anemometer

\section{Grafik laju pengeringan (bk/menit) dengan waktu (t).}

$$
\begin{array}{ll}
\mathrm{M}_{\mathrm{A}} & =\mathrm{KA}_{\mathrm{bb} 0} \times \mathrm{M}_{\mathrm{B} 0} / 100 \\
\mathrm{M}_{\mathrm{p}} & =\mathrm{M}_{\mathrm{B} 0}-\mathrm{M}_{\mathrm{A}} \\
\mathrm{M}_{\mathrm{B}} \mathrm{i} & =\mathrm{M}_{\mathrm{ki}}-\mathrm{M}_{\mathrm{w}} \\
\mathrm{M}_{\mathrm{A}} \mathrm{i} & =\mathrm{M}_{\mathrm{B}} \mathrm{i}-\mathrm{M}_{\mathrm{P}} \\
K A_{b b i} & =\frac{M A i}{M B i} \times 100 \\
K A_{b k i} & =\frac{M A i}{M p} \times 100 \\
L_{p i} & =\frac{K A b k_{(i-1)}-K A b k i}{t_{i}-t_{(i-1)}} \times 100
\end{array}
$$

Dimana,

$\mathrm{M}_{\mathrm{A}} \quad$ :Massa air dalam bahan (gram)

$\mathrm{M}_{\mathrm{P}} \quad$ :Massa bahan kering (gram)

$\mathrm{M}_{\mathrm{B}} \quad$ :Massa bahan (gram)

$\mathrm{M}_{\mathrm{K}} \quad$ :Massa kotor bahan (gram)

$\mathrm{M}_{\mathrm{W}} \quad$ :Massa wadah (gram)

KAbb :Kadar air basis basah (\%bb)

$\mathrm{KA}_{\mathrm{bk}} \quad$ :Kadar air basis kering (\%bk)

LP :Laju pengeringan (\%bk/menit) 
$\mathrm{t} \quad$ :Waktu pengeringan (menit)

4. Grafik perubahan bobot bahan (gram) terhadap waktu (t).

Susut bobot $=\frac{a-b}{a} \times 100 \%$

Keterangan : $a=$ berat awal

$\mathrm{b}=$ berat biji pada ke-n.

5. Grafik kadar air (\%) dengan waktu (t).

$M(b b)=\frac{\mathrm{w} 1-\mathrm{w} 2}{\mathrm{w} 1} \mathrm{X} 100 \%$

Keterangan :

$\mathrm{M}(\mathrm{bb})$ : Kadar air basis basah (\%)

w1 : Berat awal bahan (g)

w2 : Berat kering bahan konstan (g)

\section{HASIL DAN PEMBAHASAN}

\section{Pengeringan Pinang Muda Menggunakan Oven}

Proses pengeringan pinang muda untuk dijadikan permen pinang dilakukan di PT. Areca Agro Aceh dipabrik tersebut proses pengeringan pinang muda menggunakan metode pengovenan dimana 1 unit oven berkapasitas 8 ton menggunakan 6 unit blower yang masing-masing blower menggunakan MCB 5 amper. Proses pengeringan pinang muda dilakukan secara kontinyu selama 4 hari. Pinang muda yang sudah direbus dimasukkan ke oven dengan suhu $60 \mathrm{oC}$ yang telah ditentukan pihak PT. Areca Agro Aceh untuk proses pengeringan. Setelah 24 jam proses pengeringan dilakukan proses penyortiran untuk membuang biji-biji yang lebih kecil ukurannya, kemudian dilanjutkan proses pengeringan menggunakan suhu yang sama. Tahap selanjutnya dijangka waktu 48 jam (2 hari) dilakukan penurunan suhu sebesar $5 \mathrm{oC}$ dari $60 \mathrm{oC}$ menjadi $55 \mathrm{oC}$. Sumber panas pengeringan berasal dari pembakaran biomassa kayu yang dilakukan secara kontinyu.

\section{Hubungan Kelembaban Udara denganWaktu (RH)}

Proses pengeringan pinang muda dilakukan pada suhu $60^{\circ} \mathrm{C}$, dimana suhu pada oven pengering tersebut diatur melalui termometer. Nilai kelembaban udara didapatkan dari Humiditymeter yang ditempatkan didalam oven dengan selang waktu pengambilan data adalah 3 (tiga) jam sekali diawal proses pengeringan, dan selang waktu 6 (enam) jam sekali pada hari ke-2 sampai hari ke-4 hingga massa pinang muda kering tersebut konstan. Gambar 9. dibawah ini menunjukkan rata-rata kelembaban udara di dalam ruang pengering. 


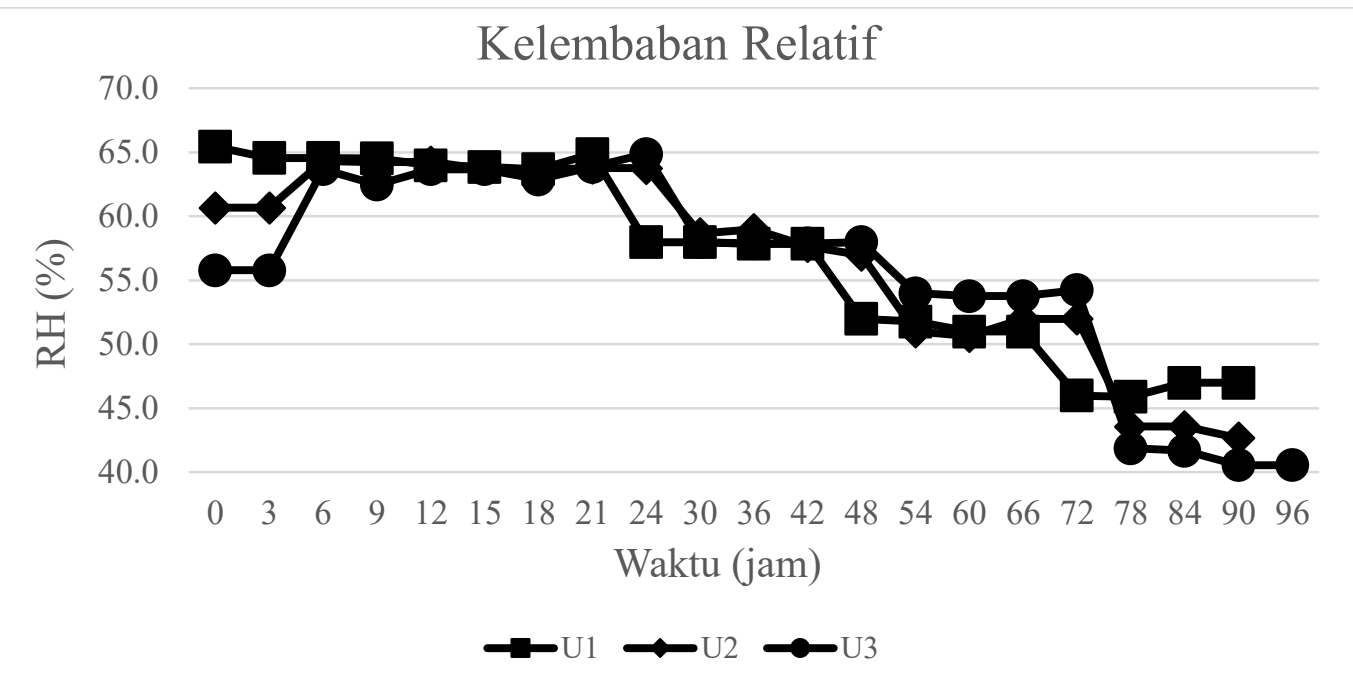

Gambar 6. Hubungan RH dengan Waktu P1, P2 dan P3

Dari Gambar 6. diatas menunjukkan bahwa selama proses pengeringan pinang muda berlangsung kelembaban relatif rata-rata ruang pengering adalah $56 \%$. Suhu udara dan kelembaban udara sangat erat hubungannya dimana disaat suhu ruang pengering berubah maka kelembaban relatif ruang pengering juga ikut berubah. Kelembaban udara yang berbanding terbalik dengan suhu udara yang dihasilkan, semakin tinggi suhu udara yang ada, maka kelembaban udara yang ada semakin kecil.

\section{Kecepatan Aliran Udara terhadap Waktu}

Kecepatan aliran udara pada penelitian pengeringan pinang muda dengan suhu $55 \mathrm{oC}$, dihitung dengan menggunakan alat Anemometer, pengamatan dilakukan dibagian ujung luar pintu oven pengeringan. Pada Gambar 10. menunjukkan rata-rata kecepatan aliran udara diruang oven pengeringan pinang muda.

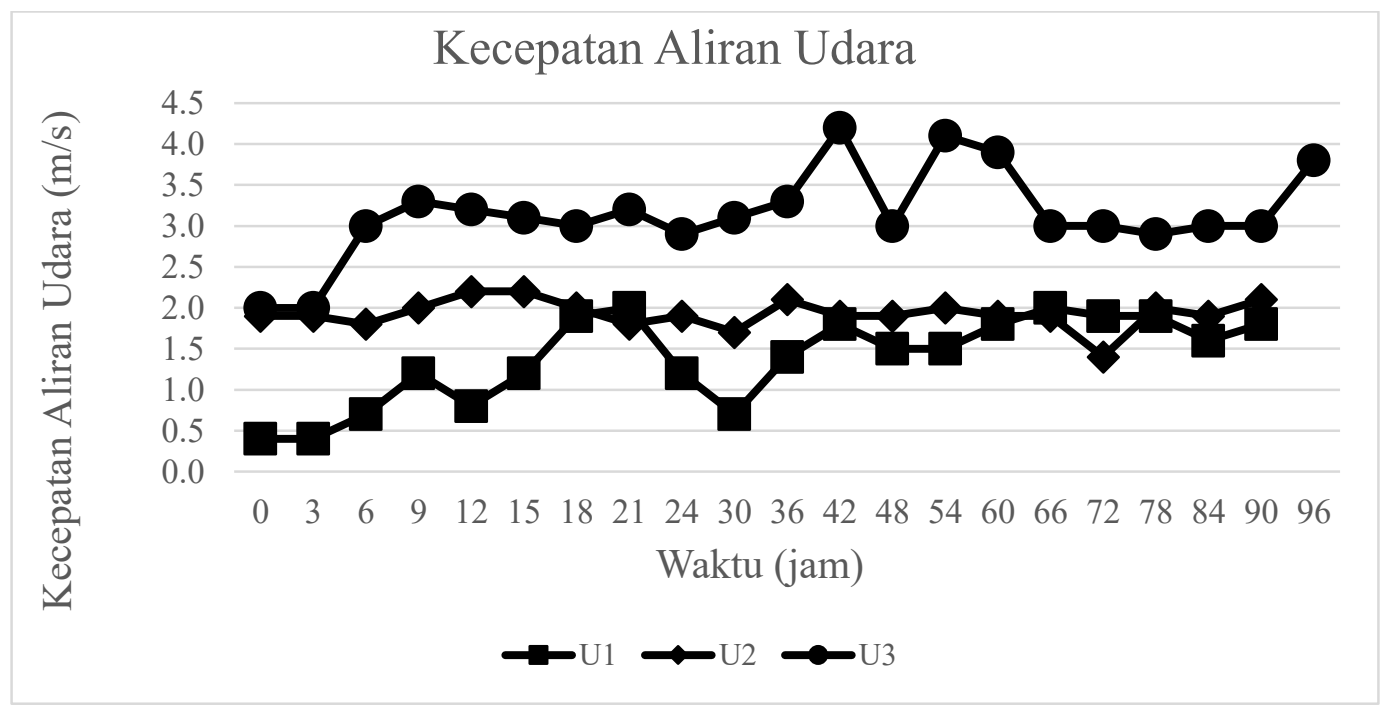

Gambar 7. Kecepatan Aliran Udara terhadap Waktu P1, P2 dan P3

Dari Gambar 7. Pada Gambar 10. diatas dapat dilihat bahwa kecepatan aliran udara pada alat oven pengeringan tidak konstan, saat pengeringan pinang muda ulangan 1 pada 3 jam pertama kecepatan udaranya berkisar $0,4 \mathrm{~m} / \mathrm{s}$, pada ulangan 2 sebesar $1,9 \mathrm{~m} / \mathrm{s}$ sedangkan pada 
ulangan 3 kecepatan udara didalam ruang pengering sebesar 2,0 m/s. Kecepatan aliran udara rata-rata pengeringan pinang muda sebesar $2,22 \mathrm{~m} / \mathrm{s}$.

\section{Perubahan Bobot Bahan}

Proses pengeringan pinang muda berlangsung sampai bobot akhir pinang muda konstan yakni 34 gram. Selama proses pengeringan berlangsung dilihat adanya perubahan bobot pinang sehingga menghasilkan lama pengeringan yang berbeda-beda pada tingkatan suhu yang sama. Pada ulangan 1 dan ulangan 2 bobot konstan pinang muda dapat tercapai pada jam ke 90, sedangkan pada ulangan 3 membutuhkan waktu 96 jam untuk mencapai berat konstan pinang muda. Dapat dilihat pada data perubahan bobot pinang muda dibawah ini

Tabel 3. Dataperubahan bobot bahan pinang muda kering.

\begin{tabular}{|c|c|c|c|c|c|c|}
\hline \multirow[t]{2}{*}{ No } & \multirow[t]{2}{*}{ Hari } & \multirow[t]{2}{*}{$\begin{array}{c}\mathrm{T} \\
\left({ }^{\circ} \mathrm{C}\right)\end{array}$} & \multicolumn{3}{|c|}{$\begin{array}{l}\text { Bobot Awal } \\
\quad(\text { gram })\end{array}$} & \multirow[t]{2}{*}{$\begin{array}{l}\text { Lama Pengeringan } \\
\text { (jam) }\end{array}$} \\
\hline & & & $\mathrm{P} 1$ & $\mathrm{P} 2$ & P3 & \\
\hline 1 & & 60 & 103 & 103 & 103 & 0 \\
\hline 2 & & 60 & 103 & 103 & 103 & 3 \\
\hline 3 & & 60 & 103 & 103 & 103 & 6 \\
\hline 4 & 1 & 60 & 103 & 103 & 103 & 9 \\
\hline 5 & & 60 & 103 & 103 & 103 & 12 \\
\hline 6 & & 60 & 103 & 103 & 103 & 15 \\
\hline 7 & & 60 & 103 & 103 & 103 & 18 \\
\hline 8 & & 60 & 103 & 103 & 103 & 21 \\
\hline 9 & & 60 & 77 & 77 & 97 & 24 \\
\hline 10 & & 55 & 77 & 77 & 97 & 30 \\
\hline 11 & & 55 & 77 & 77 & 97 & 36 \\
\hline 12 & 2 & 55 & 47 & 77 & 71 & 42 \\
\hline 13 & & 55 & 47 & 47 & 71 & 48 \\
\hline 14 & & 55 & 47 & 47 & 71 & 54 \\
\hline 15 & & 55 & 40 & 47 & 47 & 60 \\
\hline 16 & 3 & 55 & 40 & 47 & 47 & 66 \\
\hline 17 & & 55 & 40 & 34 & 39 & 72 \\
\hline 18 & & 55 & 34 & 34 & 39 & 78 \\
\hline 19 & & 55 & 34 & 34 & 39 & 84 \\
\hline 20 & 4 & 55 & 34 & 34 & 34 & 90 \\
\hline 21 & & 55 & & & 34 & 96 \\
\hline
\end{tabular}

Dari Tabel 3. ini dapat dilihat bahwa untuk mendapatkan berat pinang muda kering yang konstan, pengeringan ulangan 1 dan ulangan 2 membutuhkan waktu sampai 90 jam sedangkan ulangan 3 membutuhkan waktu pengeringan sampai 96 jam.

\section{Hubungan Kadar Air dengan Waktu}

Gambar 9 dibawah ini menunjukkan rata-rata hubungan kadar air dengan waktu selama proses pengeringan berlangsung dengan suhu $60^{\circ} \mathrm{C}$. 


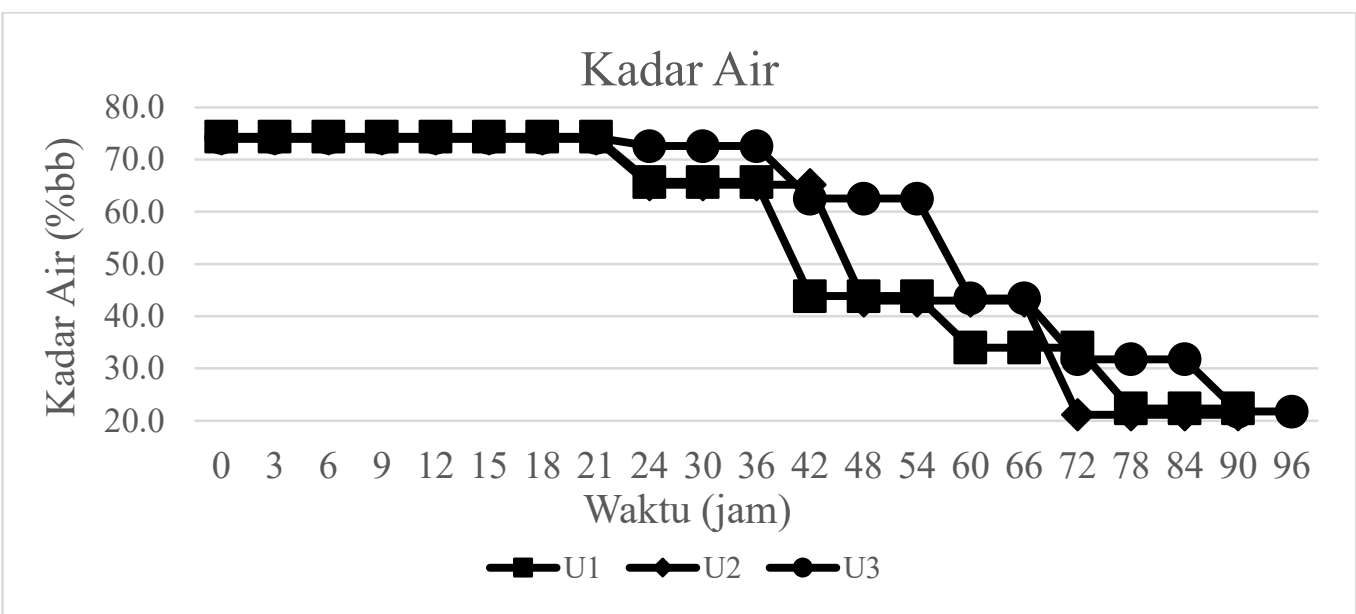

Gambar 9. Kadar Air dengan Waktu

Gambar 9. menunjukkan bahwa pada ulangan 1 kadar air awal pinang muda adalah $74,4 \%$. Selama 21 jam pengeringan pertama belum terjadinya perubahan kadar air. Perubahan mulai terjadi pada jam ke 24 sampai jam ke 90 dengan kadar air akhir pinang muda adalah 22,4\% sedangkan pada ulangan 2 kadar air awal pinang muda adalah $74,0 \%$ selama 90 jam pengeringan menghasilkan kadar akhir sebesar $21,1 \%$. Pengeringan pinang muda pada ulangan 3 kadar air awalnya sebesar 74,2\% menghasilkan kadar air akhir sebesar $21,8 \%$ selama 96 jam pengeringan. Penurunan kadar air sebanding dengan waktu pengeringan. Semakin lama waktu pengeringan, maka kadar air didalam bahan semakin berkurang, namun dengan kecepatan penurunan kadar air semakin sedikit.

\section{Hubungan Laju Pengeringan Dengan Waktu}

Gambar 10. Dibawah menunjukkan rata-rata laju pengeringan terhadap waktu pada proses pengeringan pinang muda.

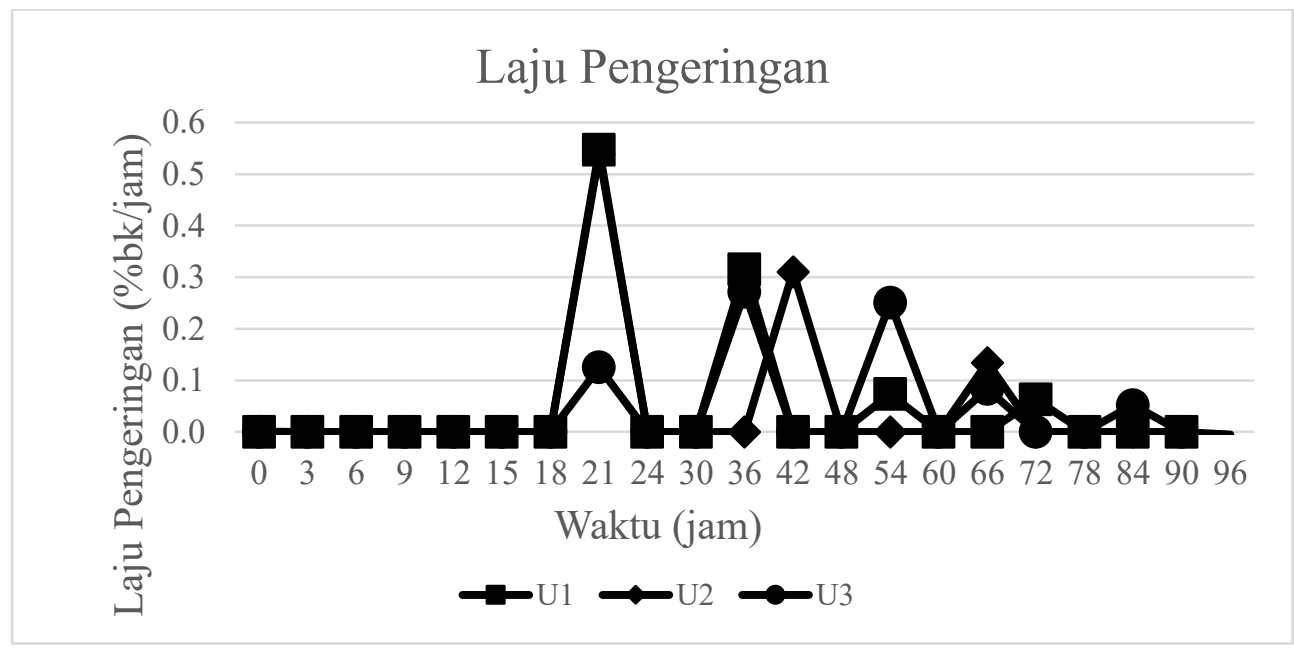

Gambar 10. Laju pengeringan dengan Waktu

Gambar 10. diatas dapat dilihat bahwa laju pengeringan rata-rata selama proses pengeringan sebesar $0,04 \mathrm{bk} / \mathrm{jam}$. Peningkatan laju pengeringan terjadi pada jam ke 21 . Laju pengeringan akan tetap berjalan dimana air bebas pada permukaan bahan telah habis. Kadar air dimana saat terjadi laju pengeringan akan tetap disebut dengan kadar air kritis. Pada pengeringan pinang muda ini tidak adanya pengeringan tetap, laju pengeringan akan menurun apabila sejalan dengan penurunan kadar air selama pengeringan. 
Taib (1988), menjelaskan bahwa air yang diluapkan dari permukaan bahan, bila tekanan uapnya lebih besardari pada uap udara yang berada disekitarnya. Tetapi, jika bahan dikeringkan dan air bebasnya dikeluarkan, maka tekanan uap air persatuan luas menjadi turun sehingga laju pengeringan akan menjadi menurun pula.

\section{KESIMPULAN DAN SARAN}

\section{Kesimpulan}

Berdasarkan hasil penelitian yang telah dilakukan, maka dapat diambil beberapa kesimpulan sebagai berikut: rata-rata kelembaban relatif pengeringan pinang muda kering sebesar $56 \%$ dengan kecepatan aliran udara pinang muda kering rata-rata sebesar $2,22 \mathrm{~m} / \mathrm{s}$. Perubahan bobot bahan untuk mendapatkan berat pinang muda kering yang konstan, membutuhkan waktu sampai 96 jam. Pengeringan pinang muda menghasilkan kadar akhir sebesar $21,8 \%$ pada akhir ulangan proses pengeringan. laju pengeringan rata-rata selama proses pengeringan pinang muda kering sebesar 0,04 $\mathrm{bk} / \mathrm{jam}$.

\section{Saran}

Untuk mendapatkan kecepatan udara yang konstan direkomendasikan penambahan blower pada ruang pengeringan sehingga dapat mempercepat laju pengeringan pinang muda.

\section{DAFTAR PUSTAKA}

AOAC. 1984. Official Methods of Analysis of The Association of Official Analytical Chemistry. 14th Ed. Virginia : AOC, Inc

Awang, M. N. 1986. "Estimination of arecoline contents in commercial areca (Batel) Nuts and Its Relatin to Oral Precancerous Lesions". Singapore Medicine Journal. 27 (4) : 317 320

Brooker, D. B. 1992. Drying And Storage Of Grains and Oilseeds. An AVI Book Published by Van Nostrand Rainhold, New York

Corzo, O., Bracho, N., Vasquez, A. (2008). Energy and Exergy Analysis of Thin Layer Drying of Coroba Slices. Journal of Food Engineering, 86, 151-161.

Cronguist. 1981. Teknologi benih. CV Rajawali. Jakarta.

Desrosier,N,W. 1998. Teknologi Pengawetan Pangan. Universitas Indonesia. Jakarta.

Gumbira. 1979. Pengolahan hasil pertanian nabati. Institut Pertanian Bogor. Bogor

Juandi M. 2016. Karakterisasi pengaruh suhu terhadap parameter fisi biji pinang hasil pengeringan menggunakan alat tipe kabinet dengan limbah tempurung kelapa sebagai sumber panas.Skripsi. FMIPA Universitas Riau. Riau. 